Joseph L. Grabau ${ }^{1}$

\title{
The Limits of Grief in Augustine of Hippo's Sermones 172-173 and Sermo 396
}

\section{Introduction}

In the texts which I intend to examine below, Augustine of Hippo refers explicitly neither to pandemics nor to plagues. What readers will find, instead, is exploration of the author's thinking in two respects: (1) a brief, critical reading of key passages from the book of Genesis in the City of God, where Augustine formulates a mature theology of both death and human emotion; and (2) a generous and compassionate approach to these phenomena as bishop and pastor, on display in a handful of exemplary public sermons (Sermones 172-173 and Sermo 396). In turning to Augustine's intensely philosophical speculations on the human body, emotions and (original) sin, we find the basis for an important cognitiv-

1 Joseph L. Grabau, Assistant Professor of Philosophy and Theology at the Mexican American Catholic College - and Lecturer at the University of the Incarnate Word's Pastoral Institute - in San Antonio, Texas (U.S.A.); email: grabau@uiwtx.edu; ORCID: 0000-0002-0919-4150. Research for this study was supported by a postdoctoral mandate of the KU Leuven's Research Council entitled, An Early Christian Anthropology/ Theology of Death: Rhetorical Forms and the Therapy of Grief (3H190262). In addition, this text has been adapted from a conference paper given for the $45^{\text {th }}$ Patristics, Medieval, and Renaissance International Conference, a virtual event hosted by Villanova University (U.S.A.), 16-18 October 2020. I offer my thanks to James Wetzel for graciously moderating the session, to Kevin Hughes and colleagues for orchestrating the event, and to my co-participants for their reception. I also wish to thank my advisors at Leuven: in particular Mathijs Lamberigts, especially for his incisive commentary on a draft of this article, and Anthony Dupont, for guidance of this project from the start. 
ist, philosophical theory of human nature ${ }^{2}$. So prominently positioned within the perspective of Scripture, in the City of God and elsewhere Augustine also adapts or synthesizes Stoic and Platonic views, despite at times taking a combative approach in his polemical agenda. Yet no less in his pastoral response to the concrete realities of lived experience, including the finality of death and vividness of emotions, Augustine maintains insights into human nature and motivation occasioned by his philosophical studies. His pastoral response is clear: consoling those who mourn, weeping with those who weep (cf. Rom 12:15). In this respect, Augustine mirrors the practices of Jerome and Ambrose of Milan, who in their own funeral orations exhibited a remarkable display of emotional restraint mixed with genuine sympathy and personal sorrow ${ }^{3}$. It is on

2 S. Byers, Perception, Sensibility, and Moral Motivation in Augustine: A StoicPlatonic Synthesis, Cambridge 2013 offers the basic framework for my analysis, often proposing similar readings to sermons identified below now studied in some greater detail. For the global impact of Stoic thought upon Augustine, see also M. Colish, The Stoic Tradition from Antiquity to the Early Middle Ages, v. 2: Stoicism in Christian Latin Thought through the Sixth Century, Leiden 1985, p. 142-238; on Augustine's reception of the Stoic philosophy of emotion, see J. Brachtendorff, Cicero and Augustine on the Passions, REAug 43 (1997) p. 289-308 and the more recent contribution of G. Yuan, Rethinking Augustine's misunderstanding of the Stoic therapy of passions: a critical survey of metriopatheia and apatheia, "Scottish Journal of Theology" 72/3 (2019) p. 308-323; on the relevant influence of Platonic trends, see for example G. Van Riel, Mens immota mota mane: Neoplatonic Tendencies in Augustine's Theory of the Passions, "Augustiniana" 54/1 (2004) p. 506-531, which philosophical tradition occupies a less prominent position here. Readers seeking further inroads to the ancient literature concerning the Platonic and Stoic therapy of the passions - especially in contact with the Augustinian, patristic tradition - will do well to consult these secondary sources for further guidance; presently, I focus my considerations upon the texts of Augustine.

3 See J. Cavadini, Ambrose and Augustine de bono mortis, in: The Limits of Ancient Christianity: Essays on Late Antique Thought and Culture in Honor of R. A. Markus, ed. W. Klingshirn - M. Vessey, Ann Arbor 1999, p. 232-249; H. Kotila, Mors, mortalitas, in: Augustinus Lexikon, v. 4, ed. R. Dodaro - C. Mayer - C. Müller, Basel 2012, p. 8997; I. Ramelli, Death, in: Encyclopedia of Ancient Christianity, v. 1, ed. A. Di Berardino, Downers Grove 2014, p. 673-681; É. Rebillard, In Hora Mortis: Évolution de la pastorale chrétienne de la mort aux IVe et Ve siècles dans l'occident latin, BEFAR 283, Rome 1994. Among the vast literature, D. Burt, Augustine on the Authentic Approach to Death, "Augustinianum" 28/3 (1988) p. 527-563 is also a useful point of entry. For precedent within and further attention to the North African context, see J. Scourfield, The De Mortalitate of Cyprian: Consolation and Context, VigCh 50/1 (1996) p. 12-41 and V. Saxer, Mort et culte des morts à partir de l'archéologie et de la liturgie d'Afrique dans l'oeuvre de saint Augustin, "Augustinianum" 19/1 (1978) p. 219-228. 
this point that Augustine's philosophical-theological reading of Genesis and the letters of Paul, together with his public sermons that pertain directly to grief and mortality, each bears upon the thematic concerns of this special issue.

This topic of human emotion is a recurrent theme in early Christian literature and ancient philosophy, to be sure. Though a concern for both Plato and Aristotle, the Hellenistic and Roman school of the Stoics presented doctrines of inward tranquility or apatheia as a distinctive teaching ${ }^{4}$. It became a shared ideal, first for Plotinus and the Cappadocians, yet also for the Latin Fathers, including St. Augustine 5 . Drawing upon various theories of the human soul and the ideal of virtue as a stable habit of character, as well as views of the world of nature and metaphysics, authors sought to understand and properly regulate the human spirit's tendency towards emotive responses to life's events and the soul's inner landscape ${ }^{6}$.

A key difference emerges in the ancient tradition, however, between the Platonic-Aristotelian account of human emotion and that proposed broadly by Stoic authors ${ }^{7}$. Sarah Byers identifies the shift in Stoic thought as a cognitive theory, which she attaches firmly to Augustine with modifications and synthesis drawing from the Platonic tradition. Most prominently on display in his public sermons and commentary on the Psalms, as Byers demonstrates, this view identifies emotions not as irrational impulses of the spirited or appetitive soul, but rather as resulting from poor judgments,

4 The case against grief, in particular, is made by Plato, Rep. 10, 604c-606a; yet E. Austin (Plato on Grief as a Mental Disorder, "Archive Geschichte Philosophie" 98/1 (2016) p. 1-20) describes this more common view as the "Stoic Reading" of Plato, over and against which the author proposes a "Conflict Reading" - for which grief is "ineliminable, and sometimes appropriate". For the scope of development into the early Christian period, see especially R. Sorabji, Emotion and Peace of Mind: From Stoic Agitation to Christian Temptation, Oxford 2000. Among other prominent texts concerning the Hellenistic period in particular, one also recalls M. Nussbaum, The Therapy of Desire, Princeton 1996.

5 Byers, Perception, Sensibility, and Motivation, p. 118-126 regarding a notion the author raises of a "Stoicized Plotinus".

6 In this broader landscape, Martin Laird, Gregory of Nyssa and the Grasp of Faith: Union, Knowledge, and Divine Presence (Oxford Early Christian Studies), Oxford 2004, p. 35-40 et passim helps to integrate these various philosophical influences, especially on the inner life of the mind for the early Christian saint.

7 J. Cooper (Pursuits of Wisdom: Six Ways of Life in Ancient Philosophy from Socrates to Plotinus, Princeton 2012, p. 203-214) portrays in general terms how the Stoic theory of emotion stands in contrast to those of Plato and Aristotle, which Byers explores in some greater detail with focus upon Cicero, Seneca, and Augustine, among others. 
that is a deficit or imperfection of rational self-control ${ }^{8}$. As commentators on Stoic sources are often eager to point out, however, this understanding does not presume to deny any positive experience of emotion for the wise person. Furthermore, Byers does not seem to suggest that Augustine simply adapts Stoic thought without qualification. In fact, Augustine seems to adopt mediated positions that allow for a healthy expression of grief and other so-called "disturbances", yet within the proper limits of both reason and the eschatological ordering of history to fulfillment in Christ.

Before I offer my own reading of three short sermons of Augustine which touch upon a specific human emotion, that of grief, I offer two major points of departure in Augustine's City of God. In books 9 and 14 Augustine addresses the Stoic presentation directly, while he develops significant themes of his own theology of death in conjunction with original $\sin$ in book 13. I pass over discussion of Augustine's own grief at the loss of his mother, Monnica, in book 9 of the Confessions - or the loss of his friend in book 4 - in order to restrict the scope of this brief study ${ }^{9}$.

\section{De civitate Dei 9 \& 14: Stoic-Cognitivist Views of Emotion}

In contemplating the Stoic view in City of God book 9, Augustine identifies a key issue for Stoic moral psychology, questioning whether and how an ideal Stoic may suffer moments of emotional disturbance.

8 For Byers, the link goes beyond the Stoic concept of human emotion to include all "interior speech" or "language of the mind". In this way, Stoic epistemology is shown to appear prominently and in concert with Stoic ethics in Augustine's rhetorical works. See Byers, Perception, Sensibility, and Motivation, p. 6-21. C. Oppel ("Why, my soul, are you sad?" Augustine's Opinion on Sadness in the City of God and an Interpretation of his Tears in the Confessions, "Augustinian Studies" 35/2 (2004) p. 199-236) also focuses upon the preaching of Augustine, in particular insights of his Psalm commentary.

9 Of studies on Augustine's suppressed tears in Confessiones 9, 29, see in particular P. Cary, Love and Tears: Augustine's Project of Loving without Losing, in: Confessions of Love: Ambiguities of Greek Eros and Latin Caritas, ed. C.J.N. de Paulo et al., New York 2011, p. 39-54. In drawing a developmental path from the writing of conf. and his early philosophical dialogues, through the public sermons and culminating in De civitate Dei, Cary speaks of a softening of Augustine's earnest views in Confessiones 9-10, where, as the author writes, "grief is always taken as the sign that we have attached ourselves too much to some temporal good" (Cary, Love and Tears, p. 51). 
This discussion turns upon a technical concept of "first movements" (or propatheiai), which occur prior to the moment of rational consent ${ }^{10}$. As Augustine summarizes this valuable distinction, "the fool's mind yields to these passions and gives them its mental assent, whereas the wise man, although he cannot help but experience them, retains with unshaken mind a true and stable view of what he ought rationally to seek or avoid"11. This ability to withhold consent remains, as Augustine recounts the Stoic view, "in our power" (in potestate) ${ }^{12}$. By exercising one's virtue through disciplined activity of the will, the mind remains fixed and free of disruptive passion $^{13}$.

Book 14 provides a more detailed taxonomy of Stoic views on the emotions, or passions, which itself builds upon Augustine's study of human mortality and the effects of original sin in the previous book ${ }^{14}$. In this context, death is shown to be the just penalty for the fall; thus, "If the first human beings had not sinned (nisi peccauissent), they most certainly would not have suffered this death" 15 .

10 See R. Layton, Propatheia: Origen and Didymus on the Origin of the Passions, VigCh 54 (2000) p. 262-282; Sorabji, Emotion and Peace of Mind, p. 344417; and R. Sorabji, Stoic First Movements in Christianity, in: Stoicism: Traditions and Transformations, ed. S. Strange - J. Zupko, Cambridge 2004, p. 95-107.

11 Augustinus, De civitate Dei 9, 4, CCL 47, ed. B. Dombard - A. Kalb, Turnhout 1955, p. 252-253; tr. W. Babcock, Saint Augustine: The City of God (De Civitate Dei) I-X, WSA 1/6, Hyde Park 2012, p. 283.

12 This nuance goes little further for Augustine than the classical Stoic discernment of "goods" and "advantages", which again he determines nothing more than a verbal innovation (nouitate uerborum), an issue of terms and not of substance: "Videtur ergo mihi etiam in hoc, ubi quaeritur utrum accident sapienti passiones animi, an ab eis sit prorsus alienus, de uerbis eos potius quam de rebus facere controuersiam." Later, he remarks similarly, "uerborum certamini, non rerum examine deputandum est" (Augustinus, De civitate Dei 9, 4, CCL 47, p. 252-253).

13 Augustine concludes the section with a classical reference to Virgil's Aeneid 4, 449: "mens immota manet, lacrimae uoluuntur inanes", on which see S. MacCormack, 'The Tears Run Down in Vain'. Emotions, Soul, and Body, in: S. MacCormack, The Shadows of Poetry: Vergil in the Mind of Augustine, Berkeley 1998, p. 89-131.

14 On this theme broadly, consult M. Lamberigts, Peccatum, in: Augustinus Lexikon, v. 3/4, ed. R. Dodaro - C. Mayer - C Müller, Basel 2014, p. 581-599 and M. Lamberigts, Peccatum originale, in: Augustinus Lexikon, v. 3/4, ed. R. Dodaro - C. Mayer - C Müller, Basel 2014, p. 599-615.

15 Augustinus, De civitate Dei 13, 3, CCL 48, p. 386, tr. Babcock, p. 70. This observation, of course, is squarely within the scope of the Pelagian controversy, which I will not attempt to discuss further here. 
Under fallen Adam, then, humanity experiences a disordered attachment to the body and temporal things ${ }^{16}$. One easily hears with inverted echoes the Stoic prescription of indifference to indifferent things, even if Augustine himself frequently identifies the failed autonomy of reason a primary consequence of the original sin in anti-Pelagian contexts. Yet such a disorder of the human person may appear to ascribe passions not simply to mistaken, false judgments, but something more fundamental. Thus, the cognitive theory of emotion seems to find traction in Augustine's thought, even if it is not yet clear how precisely the addition of Christian teachings maps on to the Stoic view of nature and the human soul.

Leaving to one side Augustine's distinctions for three kinds of death, death of the soul, the body, and the whole man, I wish to identify the leading role which grief thus takes in his subsequent analysis of the passions ${ }^{17}$. For Augustine isolates grief as particular among the passions, in that it reveals - in a special way - human attachment to temporality and finitude, as inescapable realities of a human nature now condemned under sin to a mortal condition. In this respect, Augustine considers also joy, desire, and fear, contemplating whether and in what respect any suffering of grief or despair may be virtuous ${ }^{18}$. As he confesses, this question is scrupulosior: "it is not easy to say whether an example of grief used in a good sense can be found", acknowledging how Stoics refused to acknowledge any grief in the mind of a wise $\operatorname{man}^{19}$.

Thus, Augustine's isolation of grief follows even after he attempts to include it among the other forms of human emotion, insofar as these are merely expressions and modifications of one's own love. Each of the passions, Augustine indicates, are in fact "nothing more than modes of willing". In this light, grief occurs, "when we dissent from something that actually does happen to us against our will" ${ }^{20}$. As modes of willing, Augustine describes the passions as "all bad, then, when the love is bad, and they are all good when the love is good"21. Here, Augustine clearly

16 See T. Nisula, Born to Die: Adam and Eve's Punishments in Augustine's Sermones ad populum, "Augustiniana" 67/3-4 (2017) p. 199-228.

17 The distinction is repeated at Augustinus, De civitate Dei 13, 12, CCL 48, p. 394-395.

18 Cf. Oppel, Why, my soul, are you sad?, p. 199, n. 1.

19 Augustinus, De civitate Dei 14, 7, CCL 48, p. 423 "scrupulosior quaestio est, utrum inueniri possit in bono" (tr. Babcock, p. 108); on the Stoic refusal, see Augustinus, De civitate Dei 14, 8, CCL 48, p. 423.

20 Augustinus, De civitate Dei 14, 6, CCL 48, p. 421, tr. Babcock, p. 106.

21 Augustinus, De civitate Dei 14, 7, CCL 48, p. 422, tr. Babcock, p. 107. 
articulates that emotions (or passions) are in themselves neither good nor bad, per se, but rather receive their moral element from the object of their attachment, which Augustine's here calls love (amor). A good love produces good forms of willing known as the four basic emotions, while a poorly chosen love will produce only evil forms of such willing. In this paradigm, the expressions of grief just as any of these other emotions is to be accepted and even considered praiseworthy, if and only if the circumstances of grief are also good, with the will attached to a good object. In this light, any grief over human beings seems more than acceptable, because death is a form of corruption: human beings are made in the image of God, however distorted by the change of nature due to the transmission of original sin. One conclusion this approach yields is that grief itself, on Augustine's view, is morally neutral. A second is that death itself is a clear privation of good, and thus not strictly the spiritual release identified by Plato and subsequently adopted by Ambrose ${ }^{22}$.

Augustine clarifies this point with his introduction of the eupathei$a i$, or "constant dispositions". Remarkably, these are corrections as it were of the four passions (or perturbationes); yet as corrections, on the Stoic view, the three eupatheiai of will, gladness, and caution, do not offer a remedy for grief ${ }^{23}$. Nevertheless, pointing to evidence in the letters of St. Paul the Apostle, for example that grief at times leads to repentance (2Cor 7:8-11), Augustine writes how "even grief itself (ipsa tristitia), despite the fact that the Stoics thought that they could find nothing corresponding to it in the mind of a wise man, is found in a good sense, especially in our writers (maxime apud nostros)" ${ }^{\prime 24}$. Yet it does not seem Augustine evidently proposes a "constant disposition"

22 See G. Madec, Saint Ambrose et la Philosophie, Paris 1974; N. McLynn, Ambrose of Milan: Church and Court in a Christian Capital, Berkeley 1994. The principal works demonstrating this position include the bishop of Milan's two orations on the death of his brother, Satyrus, and the heavily Neoplatonic De Isaac vel de anima; see also Cavadini, Ambrose and Augustine De Bono Mortis, p. 247-249.

23 Augustine writes, "In place of three of these passions the Stoics wanted to claim that there are in the mind of the wise man three dispositions which are called eupatheiai in Greek and which Cicero calls 'constant dispositions' in Latin - will in the place of desire, gladness in place of joy, and caution in place of fear. They denied, however, that there could be anything in the mind of the wise man that corresponds to distress or to pain, which, to avoid ambiguity, we have preferred to call 'grief'" (Augustinus, De civitate Dei 14, 8, CCL 48, p. 423; tr. Babcock, p. 108).

24 Augustinus, De civitate Dei 14, 8, CCL 48, p. 425, tr. Babcock, p. 110. 
so named, which stands as one of the eupatheia in order to correct the passion of grief in the wise soul ${ }^{25}$.

Instead, Augustine offers a summary treatment of the passions as a whole, on his correction of both the Stoics and the Platonists. His eschatological vision of human emotion is not so much, necessarily, a transformation of passion as disturbance into "good emotions" as simply eupatheiai evidenced on the Stoic view. Rather, he identifies a transformation of the will, which determines the moral quality of the emotion thus experienced and expressed. "Among us Christians", Augustine writes, in contrast, "the citizens of the city of God, who live according to God during the pilgrimage of this life (in huius uitae peregrinatione), feel fear and desire, pain and gladness, in accord with Holy Scripture and sound doctrine; and, because their love is right, they have all these emotions in the right way"26.

As a concession to the weakness of our human condition, Augustine acknowledges how in this life emotion may occur against our will. Yet absolute tranquility of soul, or impassibility, is not achievable in such a state, for "So long as we bear the weakness of this life, however, we certainly would not be living rightly if we did not feel these emotions at all" 27 . Conversely, the ideal of tranquility will only be possible for the Christian when sin itself is no more; though desirable, "it does not belong to this life" 28 . In the future state, there will be both love and gladness; yet, Augustine recalls, "it will

25 Evidence clearly suggests that, for Augustine passions may become healed when properly ordered by reason (see Augustinus, De beata vita 4, 25, CCL 29, p. 78 or Augustinus, De diversis quaestionibus 25, CCL 44A, p. 31, where fear is overcome by the sapiens). Nevertheless, grief (tristitia) seems to retain a stubborn quality that may resist such corrective healing, leading Augustine to speak of it as "most perplexing". The apparent indifference to each of the four classical passions at Augustinus, Confessiones 10, 14, 22, CCL 27, p. 166 refers rather to the distinctive autonomy of memory and contemplation, respectively, not precisely to transfigured grief. On these points, see P. van Geest, Ante omnia igitur opus est Dei timore converti (doctr. chr. 2.7.9). Augustine's Evaluation of Fear, in: Tractatio scripturarum. Philological, Exegetical, Rhetorical and Theological Studies on Augustine's Sermons, ed. A. Dupont - G. Partoens - M. Lamberigts, Instrumenta Patristica et Medievalia. Research on the Inheritance of Early and Medieval Christianity 65, Ministerium Sermonis II, Louvain 2012, p. 443-464.

26 Augustinus, De civitate Dei 14, 9, CCL 48, p. 426, tr. Babcock, p. 110.

27 Augustinus, De civitate Dei 14, 9, CCL 48, p. 428: "Saepe illis etiam inuiti cedimus $[\ldots]$ etiam dum nolumus flemus. Habemus ergo eas ex humanae condicionis infirmitate $[\ldots]$ sed dum uitae huius infirmitatem gerimus, si eas omnino nullas habeamus, tunc potius non recte uiuimus" (tr. Babcock, p. 112-113).

28 Augustinus, De civitate Dei 14, 9, CCL 48, p. 428: "bona plane et maxime optanda est, sed nec ipsa huius est uitae" (tr. Babcock, p. 113). 
have no fear or grief at all". Thus, grief is inescapable in our mortal human nature, yet appears on a spectrum of variance between virtuous, life-giving grief (which remains unnamed, properly) and immoral, self-indulgent sorrow. Eschatologically, both forms and all variety thereof are merely provisional, a sign and symbol of our present condition.

On this note, Augustine returns now to consider once again the first human beings, before the origin of sin and death, in a state of emotional tranquility, where they also enjoyed neither fear nor grief. Regarding the cognitive theory, Augustine indicates how it is always the human will which controls human emotion, thus in line with Byers' reading ${ }^{29}$. In what is a constructive chapter of her book, Byers also proposes certain "cognitive therapies" which aim to address and mediate the human emotions; in other words, designed to provide for human moral progress. These do not appeal to the non-rational or bodily dimension of oneself, but rather to the intellect and will. Surprisingly, Byers claims that prayer is not such an affective therapy, seemingly at odds with Augustine's advice in s. 172, that those who mourn should join in prayer and works of charity with the believing community ${ }^{30}$. Instead, the author identifies pre-rehearsal of possible future events (akin to Seneca), recollection of events in salvation history (adapted from Epictetus, as well as Cicero, Plutarch, and Seneca), meditation on the law (a reworking of Judaic culture) and referring to nature's teleological hierarchy of goods (a Stoic paradigm joined with Aristotelian

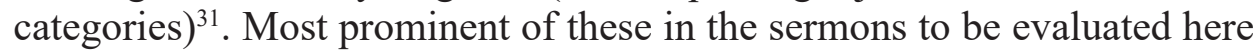
are recollection and referring; however, pre-rehearsal and meditation on the law may also be visible. Each of these refer to ways in which the passions, as wounds to the soul, may be healed and transformed.

\subsection{Death and Grief in Augustine's Sermo 172 \& Sermo 173}

For sermones 172 and 173, Augustine's biblical text is that of 1Thess 4:13, where the Apostle Paul admonishes that the faithful "not to feel sad, like those who have no hope" 32 . Both sermons were apparently given for

29 Augustinus, De civitate Dei 14, 19, CCL 48, p. 442: “cum eis consenserit, uoluntas mouet".

30 Augustinus, Sermo 172, 3, PL 38, p. 939.

31 Byers, Perception, Sensibility, and Motivation, p. 151-171.

32 Augustinus, Sermo 173, 3, PL 38, p. 939: "ut non contristemini, qumadmodum gentes, quae spem non habent" (tr. E. Hill, Sermons on the New Testament (148-183), 
a general commemoration of the faithful departed, much as All Souls in the current liturgical calendar, as contemporary editors note ${ }^{33}$. In each, Augustine provides both a theological grounding for the natural necessity of human death, as well as an option for redirecting grief and potentially mitigating its negative consequences ${ }^{34}$.

This redirection, of course, becomes consolation primarily through recalling the truth of the resurrection, thus reframing both human mortality and grief in view of certain truths of faith. Such a meditation, with the goal of moderating - though not extinguishing - grief bears striking resemblance to accepted Stoic teaching. Just as the Stoic recalls the providential ordering of nature, and the naturalness of human death, so too Augustine understands both God's providence and the inevitability of dying within the natural order of events. For different reasons, yet equally depending upon a specific set of cognitive commitments that give rise not to false judgments but objectivity, Augustine and the Stoic find room for consoling oneself in the midst of grief. Again, just as the ideal of virtue, that is, living in accord with nature, dictates a responsible engagement with the passions of fear and grief, so for Augustine the virtues of faith and hope, in particular, guide and correct the grieving soul.

In this respect, though nature may look similar for the Stoic and Augustine, of course it is the four-fold schema of ante legem, sub lege, sub gratia, and in

New Rochelle 1992, p. 255). See also Augustinus, Sermo 172, 1, PL 38, 936, where the biblical quotation instead reads, "sicut ceteri qui spem non habent". The minor shift suggests a difference of Latin text on hand for the occasion, and thus potentially a different location; cf. views of shifting Latin translations of biblical texts presented by H.A.G. Houghton, The Latin New Testament: A Guide to its Early History, Texts, and Manuscripts, Oxford 2016.

33 For translation and notes, see Sermons on the New Testament (148-183), p. 251256, where editors indicate Sermo 172 remains undated and Sermo 173 has been identified by A.-M. La Bonnardière as preached in 418. É. Rebillard, The Care of the Dead in Late Antiquity, tr. E. Trapnell Rawlings - J. Routier-Pucci, Ithaca 2009, p. 142 and p. 170 indicates that sermo 172 and sermo 173 belong to the appendix of a medieval collection known as De verbis Apostoli and have likely been transmitted as abbreviated versions of Augustine's words; see, further, G. Partoens, La collection de sermons augustiniens 'De verbis apostoli': introduction et liste des manuscrits les plus ancients, "Revue Bénédictine" 111 (2001) p. 320.

34 For this reason, both sermons may be understood with Sermo 396 in light of the Greco-Roman rhetorical forms of consolation and funeral orations; cf. Y.-M. Duval, Consolatio, in: Augustinus Lexikon, v. 1, ed. R. Dodaro - C. Mayer-C. Müller, Basel 1994, p. 1244-1247 and N. Hultin, The Rhetoric of Consolation: Studies in the Development of the 'consolatio mortis', Baltimore 1965 (Ph.D. diss.). 
pace which supports the Augustinian view ${ }^{35}$. Yes, there is a natural necessity to death, Augustine admits in both sermons, and thereby even an understandable inclination toward grieving. Clinging to life thus reflects the state of original beatitude, where human beings "would have lived without end (sine termino) if they had been willing to live without sin", since "death would not have happened to man but for the punishment that had been preceded by a grave fault" ${ }^{36}$. Augustine expands the concept of his pastoral, theological approach to sin and death, speaking of "this life [...] which is spent halfway between and before ultimate good and ultimate evil things, in the midst of middling goods and evils, in neither case the ultimate" 37 .

In this mixed state, Augustine recalls the hope of the resurrection, with the words of St. Paul firmly in mind: "when our dear ones die", he preaches, "we are saddened by the necessity of losing them, but still cherish the hope of receiving them back again" ${ }^{38}$. The alternation of goods and evils thus includes both grief and consolation, natural human pain that is "healed by the diving promise". Therefore, "in this halfway kind of life, we must hold onto [...] the gospel, 'Whoever believes in me, even though he dies, is alive' (Jn 11:25-26)"39.

Under the provision of grace, then, the resurrection offers a promise of consolation through faith and hope; but what is the extend of this hope, and how should these virtues guide our tendencies toward grief and sorrow as a passion? Firstly, Augustine admits at this point also the acceptability of "loving hearts to grieve at the death of their dear ones, but with a sorrow that will let itself be assuaged; and to shed the tears that suit our mortal condition, but that are also prepared to be consoled" 40 . Faith does not pre-

35 Oppel (Why, my soul, are you sad?, p. 207) approaches grief and tears in the Confessions under this paradigm with fruitful results. See also C. Oppel, A Theology of Tears: From Augustine to the Early Thirteenth Century, Melbourne 2002 (Ph.D. diss).

36 Augustinus, Sermo 172, 1, PL 38, p. 936: "Nec mors homini accideret, nisi ex poena quam praecesserat culpa [...] quanto magis homo, qui sic fuerat creates, ut si uiuere sine peccato uoluisset, sine termino uiueret" (tr. Hill, p. 251).

37 Augustinus, Sermo 173, 1, PL 38, p. 938: "In hac autem uita, quae media ante summa bona et ante summa mala ducitur, in medio bonorum malorumque mediorum, id est, in neutra parte summorum" (tr. Hill, p. 254).

38 Augustinus, Sermo 172, 1, PL 38, p. 936: "Contristamur ergo nos in nostrorum mortibus necessitate amittendi, sed cum spe recipiendi” (tr. Hill, p. 251).

39 Augustinus, Sermo 173, 1, PL 38, p. 938, tr. Hill, p. 254.

40 Augustinus, Sermo 172, 3, PL 38, p. 937: "Permittantur itaque pia corda carorum de suorum mortibus contristari dolore sanabili, et consolabiles lacrymas fundant conditione mortali” (tr. Hill, p. 252). 
vent such tears or the well of grief, yet it does limit them. Under a proper cognitive schema, grief becomes subsumed under higher, theological reality - most especially, the virtue of hope.

Byers views the brevity of grief as an indicator of healthy emotion, more generally, for Augustine; in light of mortality, faith and hope offer a detachment from finite goods and attention to the future state. Like Stoic ethics and physics, this reframing rests upon an "insistence on the impermanence and merely relative importance of all temporal situations and events" ${ }^{41}$. As Byers terms this cognitive recalculation, Augustine advises here a "comparative evaluation of goods", in order to moderate or control human emotions, including that of grief $^{42}$.

If such a substructure supports Augustine's pastoral admonitions, he nevertheless preaches in two directions: firstly, to supplant the theological recalibration required at the onset of severe, apparent misfortunes such as loss of life; yet, secondly, also to admonish the faithful of their calling to support the bereaved in prayer and works of charity. In this respect, he truly offers both thoughts and prayers - for the deceased and for those who mourn ${ }^{43}$.

To the first, he clarifies how Jesus himself grieved together with Mary at the death of her brother, Lazarus. Yet, "he wasn't weeping for the dead man whom he brought back to life, but for death, which man brought on himself by sinning. For if sin had not entered the picture, no doubt death would not have followed"44. Looking to the theological and biblical sources, Augustine provides necessary perspective and clarity on both the definition and cause of death itself. Building implicitly - yet with clear echoes - upon Rom 5:12, Augustine recalls how the penalty of sin brought death first to the body, and then to the soul - separating its life from $\operatorname{God}^{45}$. It is in

41 Byers (Perception, Sensibility, and Motivation, p. 75) reads this text in light of Seneca's admonition, repeated in Cicero, for Stoic emotional wounds to remain "light"; cf. Augustinus, De civitate Dei 19, 8, where Augustine states that our souls heal more quickly, the more virtuous we are. See, also, Cary, Love and Tears, p. 46.

42 Byers, Perception, Sensibility, and Motivation, p. 76.

43 In Sermo 172, 2, Augustine recalls the tradition of prayers offered on behalf of the dead and reminds his audience these are more valuable than other external, superficial displays of solidarity.

${ }_{44}$ Augustinus, Sermo 173, 2, PL 38, p. 938-939: "Non mortuum flebat, quem ipse suscitauit; sed mortem, quam sibi homo peccando comparauit. Si enim peccatum non praecessisset, sine dubio mors secuta non fuisset". Above, the second sentence of the translation is my own, departing from that of E. Hill (p. 255).

45 Augustinus, Sermo 173, 2, PL 38, p. 939; cf. Augustinus, De civitate Dei 13, 2-6, CCL 48, p. 385-389. 
this light, of course that death is "so abhorrent to nature", and why the pain of loss is often so intense as well as mysterious ${ }^{46}$.

Augustine is certainly sympathetic: "how can you not feel sad?" he asks, explaining the vivid immediacy of an absent friend or loved one $\mathrm{e}^{47}$. From the experience of being human, death presents an undeniable confrontation. Yet death itself, and even the wake of grief afterwards, retains a profound symbolic meaning. Thus, with such theological recollection in place and the fruit of the resurrection in store, Augustine challenges his audiences, "let grief(luctus) be wiped from the soul, let faith drive out sorrow (dolorem)" $" 48$.

\subsection{An Episcopal Funeral: Sermo 396}

In Sermo 396, Augustine partly shows us more of his own personal grief. Delivered in 419 at the death of a bishop, perhaps his friend Florentius, Augustine begins the sermon, remarking, "You, indeed, brothers and sisters, are looking for consolation and comfort from me. But I too need to be comforted and consoled" 49 . Eschatological language again shapes Augustine's consolatory words. We fill ourselves with the hope of heaven, for "what seems a long life [here], when it comes to an end will be reckoned as nothing" ${ }^{50}$. Thus, in both the order of salvation history unfolding, and in the final hierarchy of goods, this life is a passing breath.

However, Augustine acknowledges that no less does grief overwhelm us, upon the unwelcome though not unforeseen arrival of death. This sadness is natural, yet whatever his Stoic tendencies, Augustine embraces a broader view of the whole, of which nature itself is a part. Wisdom's tranquility is not that of Stoic indifference to indifferent things, for Augustine, for the disorder of a nature that admits mortality and grief provides an

46 Augustinus, Sermo 172, 1, PL 38, p. 936, tr. Hill, p. 251.

47 Augustinus, Sermo 173, 3, PL 38, p. 939: "quomodo autem non contristaris [...]?" (tr. Hill, p. 255).

48 Augustinus, Sermo 173, 3, PL 38, p. 939: "Pereat contristatio, ubi tanta est consolatio: detergatur luctus ex animo, fides expellat dolorem" (tr. Hill, p. 256).

49 Augustinus, Sermo 396, 1, PL 39, p. 1717: "Vos quidem, fratres, consolatorem quaeritis: sed etiam nos consolandi sumus" (tr. E. Hill, Sermons 341-400, WSA 3/10, Hyde Park 1997, p. 434). For the identification, see Sermons 341-400, p. 434, n. 1, citing O. Perler, Les Voyages de Saint Augustin, Paris 1969, p. 352-354.

50 Augustinus, Sermo 396, 1, PL 39, p. 1718, tr. Hill, p. 433. 
incomplete account. Thus, virtue is transformed by a re-envisioning of the human end, which here rests primarily not upon a Stoic courage as much as the virtues of faith and hope. These do not preclude genuine (fallen) human emotional responses, for "we feel sad, as human beings"; yet these do open the path to a new form of surpassing human nature: "So what can we do, in order not to be human?" Augustine asks ${ }^{51}$. Recall the scope of human history, the passing of ages, Augustine advises; cling to happy memories, hold fast to the instruction and example left behind. Let the memory of the deceased dwell among the living and bring us closer to $\operatorname{God}^{52}$. Augustine can scarcely say more.

\section{Conclusion}

Augustine's brevity and evident emotion in Sermo 396 does not lose sight of the transformative dimension of his pastoral teaching on death and grief. He continues to frame the shared loss and enduring pain in view of both the order of goods and the guiding light of Christian hope. Yet that hope is surely muted, both for the absence of direct mention of the resurrection - so clearly articulated in Sermo 172 and Sermo 173 - as well as neglect of original sin. Yet grief, restrained and prevented from becoming despair through a kind of intellectual effort of both the mind and the will, remains. In this way, Augustine shares affinity with Stoic theories of the emotions, using key doctrines and biblical texts to frame our human mortality and grief itself, while providing also corrective tools for accepting and appropriating such realities within a larger whole.

Grief, in turn, is a natural human response to human finitude. On Augustine's theological model, it remains intrinsically linked to death as the punishment for sins, which should be further validated. A com-

51 Augustinus, Sermo 396, 2, PL 39, p. 1718: "In hoc enim habemus tristiam de homine sicut homines. Quid ergo faciemus, ut non simus homines?" (tr. Hill, p. 433).

52 Augustinus, Sermo 396, 2, PL 39, p. 1718, tr. Hill, p. 434: "He is living in God's presence, and so is blessed; let him live in your presence, so that you too may be blessed". On this point, readers invested in pursuing the link with Pelagianism in a polemical context will find the following two studies of importance: R. Dodaro, 'Christus Iustus' and Fear of Death in Augustine's Dispute with Pelagius, in: Signum Pietatis: Festgabe für Cornelius Petrus Mayer, OSA, zum 60. Geburtstag, ed. A. Zumkeller, Würzburg 1989, p. 341-361; J. Valero, El Estoicismo de Pelagio, in: Liber Amicorum: miscelánea homenaje en recuerdo del Prof. Dr. Juan Bautista Valero Agúndez, ed. E. Gil Coria - A. Valastro Canale, Madrid 2003, p. 51-78. 
ponent of the concupiscent human's internal ordering, the tendency to grieve prefigures a theological expression of grief, on display most clearly in the person of Christ. Although the other emotions may become, for Augustine, rightly ordered even in this life, looking ahead to the future restoration of all things, grief is a shadow cast upon our present state that is also essentially backward-looking. It results from the fall and may be moderated by the hope of the resurrection, the defeat of sin and death on Christ's cross. Symbolically, it provides a natural witness to the unnaturalness of death ${ }^{53}$. It compounds the pain of loss suffered at death, yet theologically it may also be reconfigured to salvation history at all poles: its absence at creation, its reign with sin and death, its distant memory in the time to come.

\section{The Limits of Grief in Augustine of Hippo's Sermones 172-173 and Sermo 396}

(summary)

This contribution explores select sermons of Augustine relating to the pastoral and existential phenomena of grief and human mortality (sermones 172-173 and 396). In particular, it evaluates these themes in conversation with philosophical reflections on human nature in the City of God, Books 13-14. Drawing upon Platonic and Stoic views in the latter, St. Augustine prefers a more compassionate and permissive understanding of human emotion in the former. Nevertheless, the author argues that while Augustine makes extensive textual appeal to Pauline and Johannine sources, which is likewise evident in his philosophical work, he remains implicitly committed to a philosophical theory of emotion also in his preaching. In order to support this claim, I first present the philosophical traditions at work within the biblical horizon of the City of God, through a careful reading of pertinent texts, including work of Sarah Byers. Second, I attend to shifts of tone and emphasis detected in three public sermons, two of which have been successfully dated to 418 and 419, where evident differences of genre and audience help to account for Augustine's heightened pastoral sensitivity. This comparative approach illuminates, finally, how the bishop of Hippo maintains philosophical continuity as he navigates pastoral responsibilities.

Keywords: Augustine of Hippo; preaching; philosophy of Emotions; Stoicism

53 On this point, also, A. Dupont, Augustine's Anti-Pelagian Interpretation of Two Martyr Sermons. Sermones 299 and 335B on the Unnaturalness of Human Death, in: Martyrdom and Persecution in Late Antique Christianity: Festshrift Boudewijn Dehandschutter, ed. J. Leemans, BETL 241, Leuven 2010, p. 87-102. 


\section{Bibliography}

\section{Sources}

Augustinus, Sermones ad populum, ed. J.-P. Migne, PL 38, Paris 1841, tr. E. Hill, Sermons on the New Testament (148-183), WSA 3/5, New Rochelle 1992.

Augustinus, Sermones ad populum, ed. J.-P. Migne, PL 39, Paris 1845, tr. E. Hill, Sermons 341-400, WSA 3/10, Hyde Park 1997.

Augustinus, De civitate dei libri I-X, XI-XXII, ed. B. Dombard - A. Kalb, CCL 47-48, Turnhout 1955, tr. W. Babcock, The City of God (Books 1-10, 11-22), WSA 1/6-7, Hyde Park 2012-2013.

\section{Studies}

Austin E., Plato on Grief as a Mental Disorder, "Archive Geschicte Philosophie" 98/1 (2016) p. 1-20.

Byers S., Perception, Sensibility, and Moral Motivation in Augustine: A Stoic-Platonic Synthesis, Cambridge 2013.

Cary P., Love and Tears: Augustine's Project of Loving without Losing, in: Confessions of Love: Ambiguities of Greek Eros and Latin Caritas, ed. C.J.N. de Paulo et al., New York 2011, p. 39-54.

Colish M., The Stoic Tradition from Antiquity to the Early Middle Ages, v. 2: Stoicism in Christian Latin Thought through the Sixth Century, Leiden 1985.

Cooper J., Pursuits of Wisdom: Six Ways of Life in Ancient Philosophy from Socrates to Plotinus, Princeton 2012.

Dupont A., Augustine's Anti-Pelagian Interpretation of Two Martyr Sermons. Sermones 299 and 335 B on the Unnaturalness of Human Death, in: Martyrdom and Persecution in Late Antique Christianity: Festshrift Boudewijn Dehandschutter, ed. J. Leemans, BETL 241, Leuven 2010, p. 87-102.

Duval Y.-M., Consolatio, in: Augustinus Lexikon, v. 1, ed. R. Dodaro - C. Mayer C. Müller, Basel 1994, p. 1244-1247.

Hultin N., The Rhetoric of Consolation: Studies in the Development of the 'consolatio mortis', Baltimore 1965 (PhD diss.).

Layton R., Propatheia: Origen and Didymus on the Origin of the Passions, "Vigiliae Christianae" 54 (2000) p. 262-282.

Houghton H.A.G., The Latin New Testament: A Guide to its Early History, Texts, and Manuscripts, Oxford 2016.

Kotila H., Mors, mortalitas, in: Augustinus Lexikon, v. 4, ed. R. Dodaro - C. Mayer C. Müller, Basel 2012, p. 89-97.

Lamberigts M., Peccatum, in: Augustinus Lexikon, v. 3/4, ed. R. Dodaro - C. Mayer C Müller, Basel 2014, p. 581-599. 
Lamberigts M., Peccatum originale, in: Augustinus Lexikon, v. 3/4, ed. R. Dodaro C. Mayer - C Müller, Basel 2014, p. 599-615.

MacCormack S., The Shadows of Poetry: Vergil in the Mind of Augustine, Berkeley 1998. Oppel C., "Why, my soul, are you sad?" Augustine's Opinion on Sadness in the City of God and an Interpretation of his Tears in the Confessions, "Augustinian Studies" 35 (2004) p. 199-236.

Van Riel G., Mens immota mota mane: Neoplatonic Tendencies in Augustine's Theory of the Passions, "Augustiniana" 54 (2004) p. 506-531.

Rebillard É., The Care of the Dead in Late Antiquity, tr. E. Trapnell Rawlings - J. Routier-Pucci, Ithaca 2009.

Sorabji R., Emotion and Peace of Mind: From Stoic Agitation to Christian Temptation, Oxford 2000.

Sorabji R., Stoic First Movements in Christianity, in: Stoicism: Traditions and Transformations, ed. S. Strange - J. Zupko, Cambridge 2004, p. 95-107. 